\title{
Stock Exchange Mutual Funds as the Drivers of the Stock Market Development in Terms of Profitability and Alternatives
}

\author{
Larisa Yuzvovich ${ }^{1}$, Veronika Frais ${ }^{1}$, and Gaukhar Kodasheva ${ }^{2}$ \\ ${ }^{1}$ Ural State University of Economics, 620144 Ekaterinburg, Russia \\ ${ }^{2}$ Eurasian National University named after L.N. Gumilyov, 010008 Astana, Kazakhstan
}

\begin{abstract}
The current stagnation in the development of the Russian stock market determines the need to master new investment instruments or to improve the activities of existing ones. The development of global stock markets clearly emphasizes the "immaturity" of the Russian stock market. Present situation indicates the need for the introduction and development of new investment instruments. This fact encouraged the development of ETFs in Russia. Russian ETFs have a relatively short story, but this does not prevent them from expanding the scope of activities, gaining momentum and demonstrating a high degree of profitability, which is a significant competitive advantage over other unit investment funds. The study offers the overlook of exchange-traded investment funds' activities as a hybrid with foreign ETFs and an alternative to Russian domestic unit investment funds, which reach a high level of profitability in modern conditions.
\end{abstract}

\section{Introduction}

Evidence suggests that the collective investment market in Russia began not earlier than at the end of the $20^{\text {th }}$ century. The advent of collective instruments brought in innovations to the institutional structure of the Russian stock market. Simultaneously, a multifaceted change in the innovation industry and digitalization provoked the need to develop new financial instruments. For several reasons in a new global economy there is a fresh tool, i.e. "exchangetraded unit funds", also known as ETF (in foreign countries these funds are called "Exchange Traded Funds"), which become increasingly popular.

A notable feature of exchange-traded funds is that they act as a new type of derivative financial instrument that allows trading on a stock market, therefore, the term "exchangetraded fund" or "ETF" can be interpreted due to the specifics of the investor's purchase/sale of a "share" in the fund. The purchase is allowed only within the rules of a functioning stock exchange.

A key issue, related to ETFs, is that they are specifically formed pools of securities, mixed with other assets or taken individually, and they make up an exchange index and tracks it. A notable example is a well-known index "the Standarts \& Poors 500" which is a US stock exchange index, indicating the cumulative change in the level value of the leading assets of US companies, attributed to the form of shares (equal to the number of 500 companies). The Moscow Exchange created its own IMOEX index, which includes the most liquid shares of 
Russian companies. Some Russian ETFs which trade in the Moscow Stock Exchange also include foreign securities. Alongside, there are some Russian ETFs which are combined shares pools of leading Russian companies produced for a foreign market to trade in foreign currency, i.e. the euro and the US dollar [1].

The history of ETFs development is an exciting story with a strong correlation depending on geographic locations. There is much evidence that currently the USA globally determine the global ETF trends. However the situation is gradually developing. For example, in 1990 Toronto stock exchange began trading first ETFs in Canada. Interestingly, the first Russian ETF appeared not so long ago, only in 2013. Russian exchange-traded funds, or in other words "ETFs under the Russian law" function as a relatively innovative tool in Russian stock market. One of the most important innovations is the Russian ETF from Sberbank which started its operation on 17 September 2018 and gained a considerable popularity among investors.

\section{Materials and methods}

There is a growing body of business literature which offers analytical information on the exchange-traded fund market. A considerable amount of digital analytical and academic literature has been published on this topic. These are the publications of such prominent media as: Investment, Morningstar, ETF.com, Company Institute. The most fundamental scientific papers describing ETFs belong to the pen of sich authors as: L. Deville "Exchange Traded Funds : History, Trading and Research,

2008", Charupat and Mew "The Pricing Efficiency of Leveraged Exchange Traded Funds: Evidence from The US Markets, 2013", Madhavan “ETF: An Overview of Institutions, Trading and Impacts, 2014".

In his scientific work, L. Deville reveals an approach to understanding ETFs as an innovative instrument for stock markets. He stresses that ETFs are one of the significant successes in financial innovation since the advent of financial futures. Like index funds, ETFs aim to accurately reproduce the performance of the underlying indices, reflect tax efficiency and have low management fees [2].

It is a common knowledge that ETFs were originally developed in the United States by the American Stock Exchange (AMEX), but soon faced a fierce trading competition. Before the NYSE ventured into ETFs, these securities were already traded on Nasdaq InterMarket, regional exchanges and Island Electronic. For the first time in its history, the NYSE began trading Qubes ETF assets in 2001. In 2004, Nasdaq-100 Index Tracking Stocks changed AMEX to Nasdaq. In 2005 Barclays' Global ETF competes with existing index securities: index component stocks, futures index, options, mutual fund (MIF) indices and closed-end funds.

Undoubtedly, ETFs can be viewed as surplus assets that fill a gap in investor needs.

There are three notable approaches to the scientific research of ETFs. The approaches can answer three important questions from an empirical point of view:

- Does the specific ETF structure allow to raise ETF pricing?

- Are ETFs an alternative to traditional index mutual funds?

- What is the impact of the emergence of ETFs on trading and market quality in terms of index components and derivatives?

Other ETF empirical research projects describe a variety of topics such as competition between trading platforms, the shape of the demand curve, or the practical application of ETFs.

Evidence suggests that ETF market experienced its spectacular peak in 1999 with the launch of the Nasdaq-100 Index Tracking Stock, commonly known as Qubes, its 
initial ticker is QQQ, which eventually was changed to QQQQ. In its second year of trading, the average daily trading volume was 70 million shares, which was $4 \%$ of the Nasdaq's total trading volume. It is the popularity of this fund that has raised investors' awareness about other ETFs and about the market in general. Over the years ETFs are gradually becoming an alternative to the traditional non-traded mutual investment funds [2, p . 3].

In case of Europe, European Stock Exchange started the list of its first ETF in 2000. The first ETF deals emerged on the territory of the Federal Republic of Germany, namely "Deutsche Börse" (German Stock Exchange) and "London Stock Exchange". The competition intensified with the advent of Stockholm Stock Exchange at the end of 2000, EuroNext in January 2001, trading in Paris and Amsterdam. Brussels began trading in October 2002 and the Swiss Stock Exchange joined the initiative in March 2001 [3]. In 2002, Helsinki Stock Exchange for the first time in its history presented its first ETF - IHEX 35, while the Borsa Italiana (Italian stock exchange) in September also opened the ETF segment. Relatively later, the Icelandic Stock Exchange began to operate ETFs in December 2004, the Norwegian Stock Market in March 2005, and the Austrian Stock Market in November 2005.

As of the end of 2005, 11 stock exchanges covered more than 160 ETFs with asset growth at an annual rate of $60 \%$, and a volume of more than 45 billion euros. Following a similar trend as in the US, stock exchanges started to track a vast regional variety of equity index ETFs. After only 5-6 years, respectively, EuroNext and Deutche Börse formed 77 and 95 ETFs respectively, which included indices of the euro area, emerging indexes countries, indices of various sectors of economy.

Despite the current economic and political instability, the ETF industry has continued to experience popularity and growth since the introduction of the first ETFs. In the process, new records for the number of ETFs were set, the rapid growth of assets continues and it is expected that by 2021 they will have reached the mark of 7 trillion US dollars [4]. The secret of the industry growth is not only in its massive scale, but also in the original idea of ETFs. The historical development of the American and European markets influenced the emergence of a variety of ETFs that satisfy the investment needs of global investors. Undoubtedly, international ETFs are among the most complex types of ETFs. First international ETFs were presented in 1996 by Black Rock Inc.

The purpose of international ETFs is to help every investor, both institutional and individual, gain access to promising global capital market indices on the stock exchanges of their countries. Previously, it was difficult for investors to directly invest in certain foreign markets due to a number of restrictions on international capital flow, such as capital market rules, exchange rules, high transaction costs, high information costs. These barriers stimulated the innovation of many investment products to promote international investment. Among these popular international products are: International Mutual Fund (IMF), American Depositary Receipts (ADR), Country Closed-End Funds (CECF), International ETF Funds. International ETFs are the most popular due to their unique hybrid structure, which simultaneously shares the characteristics of stocks and mutual funds.

International ETFs have some very distinctive features such as continuous trading, higher international diversification, lower management fees and a higher tax rate [5]. According to Engle and Sarkar (2006), international ETFs trade at a higher premium or with a discount due to the time difference between the international ETF markets and benchmark indices. Heugen and Matthew (2009) argue that asynchronous trading hours cause information asymmetries in the ETF market, which prevents international ETFs from fully replicating their underlying indices.

On the question of the scientific analysis of ETFs, it is critical to understand that the scientific community interprets the term "exchange traded fund", also known as ETF, according to different approaches of the authors. The famous 
scholar A.E. Abramov formulates the definition of ETF which is as follows, "an exchangetraded investment fund which is a portfolio of assets, and securities, issued as a pool of these assets and which certifies its ownership." Another group of scholars formulate their concept of ETF funds, according to which, these are "mutual investment exchange-traded funds", they are the type of a legal form, known as "the investment funds that issue and amortize securities traded on the stock exchange and establish the ownership on the property of the investment fund portfolio" [6].

Based on the fundamental research of foreign scientists, we can summarize the fact that the research of Russian economists is based on a comparative analysis of the characteristics of the activities of exchange-traded investment funds (ETFs) and traditional "unit investment funds" (UIFs). On this basis, V.H. Dedegkaev, I.A. Sopoeva and D.R. Kamberdieva, formulated the concept of an ETF as an "exchange-traded fund, which acts as a commodity value, which allows to track an index, commodity, bonds or basket of assets like an index fund, the hallmark of which is worth noting the high the level of daily liquidity at a low fee, relative to mutual investment funds, which indicates an advantage and makes them an attractive alternative for individual investors" [7].

Formulating the term "stock exchange investment funds" as "an ETF in the form of a collective investment which allows an investor, not having a great contribution to form the most diversified investments in accordance with all the rules of investment", formulated by I.A. Sopoeva [8]. I.A. Sopoeva also notes that "the Exchange Traded Funds are a foreign investment vehicle, stocks and bonds, which form the exchange-traded fund, to a greater extent - foreign, under the foreign jurisdiction". An advantageous feature of the functioning of these funds is that investment in ETFs does not limit placement only in stocks and bonds; assets are also various money market instruments, quoted precious metals, exchange commodities of industrial corporations and holdings, and even real estate.

\section{Results and discussion}

In this paper, we show that ETF funds are special types of funds which are formed by stock exchange assets. There is a similarity between a stock mutual investment fund and an ETF fund. Both types of funds belong to a "collective investment" sector, therefore, simultaneously investing in several securities. And both of them are investment tools, such as "mutual funds which are regulated by the laws of the Russian Federation, etc."

The activity of stock mutual funds, in addition to Russian, is also regulated by international law. Such investment instruments as exchange-traded funds, or ETFs, provide a high level of investments' diversification by various criteria which are as follows: the type of industry, the type of financial instruments, geographical locations.

The current activity of ETFs on the Russian stock market is carried out at the Moscow Exchange, the funds reinvest payments on assets are provided in the form of shares and bonds. You can become a "shareholder", i.e. a holder of an ETF unit, through an intermediary in the form of a broker, since this option protects the investor's rights, in accordance with the legislation of the Russian Federation, while the obligation of taxation is automatically transferred to an intermediary (broker or management company).

The activity of exchange-traded mutual investment funds is comparable to the principle of activity of open-ended mutual investment funds, the shares of which are purchased or sold without limitation in time. The difference lines of these funds are formulated according to the following criteria: portfolio composition, transparency, liquidity, commission and risks (table 1). 
Table 1. The main differences between exchange-traded funds and open-end mutual funds

\begin{tabular}{|c|c|c|c|}
\hline No. & Index & Exchange-traded funds & $\begin{array}{l}\text { Open-ended unit mutual investment } \\
\text { funds }\end{array}$ \\
\hline 1 & $\begin{array}{l}\text { Portfolio } \\
\text { comsition }\end{array}$ & $\begin{array}{c}-\quad \text { Investments in foreign } \\
\text { securities; } \\
\text { company invests funds in a } \\
\text { specific list of assets in a clear } \\
\text { ratio, relative to the index, which } \\
\text { is focused on the stock exchange } \\
\text { unit investment fund. }\end{array}$ & $\begin{array}{l}\text { - Investments in Russian securities. } \\
\text { - The management company } \\
\text { independently determines the structure of } \\
\text { the investment fund. }\end{array}$ \\
\hline 2 & Transparency & $\begin{array}{l}\text { Full transparency of the investment } \\
\text { portfolio structure. }\end{array}$ & $\begin{array}{l}\text { The structure of the investment portfolio is } \\
\text { disclosed, i.e. once a month. }\end{array}$ \\
\hline 3 & Liquidity & $\begin{array}{l}\text { Absolute liquidity, i.e. buy / sell at } \\
\text { any time (continuous change in } \\
\text { quotes). }\end{array}$ & $\begin{array}{l}\text { Repayment, only through the management } \\
\text { company or agent; Calculation up to } 10 \\
\text { working days. }\end{array}$ \\
\hline 4 & Commission & $\begin{array}{l}\text { The commission for } \\
\text { the management of the investment } \\
\text { portfolio varies in the range of } 0.2- \\
0.8 \% \text { per annum. }\end{array}$ & $\begin{array}{l}\text { Opened mutual fund commission - from } 1 \\
\text { to } 5 \% .\end{array}$ \\
\hline 5 & Risks & $\begin{array}{l}\text { Correlation with indices provides a } \\
\text { minimum level of risk. }\end{array}$ & $\begin{array}{l}\text { A moderate level of risk, due to "manual } \\
\text { control", which provides a high level of } \\
\text { profitability. }\end{array}$ \\
\hline
\end{tabular}

Consequently, exchange-traded funds are the most liquid financial instrument, in contrast to mutual investment funds. This may be explained by the option of free buying / selling on the stock exchange. It is worth noting that there are important differences between ETFs and mutual funds: the asset value of exchange-traded investment funds has a direct correlation with the value of the corresponding index in the current time mode, this value is determined daily - once a day; operations and transactions with mutual investment funds are carried out through the participation of a management company, if you analyze the level of commission, then for ETFs it is about $1 \%$ in the Russian stock exchange market, $0.1 \%$ - in the foreign stock exchange market, at the same time, the commission for mutual investment funds reaches up to $4 \%$ [9].

Another disadvantage of Russian mutual funds is that they do not pay dividends, while a number of ETFs, in the event of a decrease in the value of the index, guarantee the payment of dividends, and are also able to carry out transactions using leverage.

A change in the portfolio of mutual investment funds is carried out by exchanging one mutual investment fund for another, within the jurisdiction of one management company, as for the portfolio of an exchange-traded investment fund, it is necessary to sell an asset and then purchase another without restrictions.

The largest share of open-ended mutual investment funds is concentrated under the management of "Sberbank Asset management", which is the absolute leader in the trust management market and acts as a driver for the development of the mutual investment funds market. According to the Extel Survey, "Sberbank's analytical team has been recognized as the best in Russia for several years (2014-2019)" [10].

Mutual investment funds under the management of "Sberbank Asset Management" are $1 / 3$ of the funds raised in open-ended mutual funds. At the end of 2019 , the value of the net assets of the open-ended mutual fund of Sberbank reached 133 billion rubles, this is $40 \%$ more than in the previous year 2018) [11].

The functioning of mutual investment funds, in aggregate, has a positive trend, among the leaders in terms of profitability are the mutual fund "Sberbank-Global Internet" (the annual return on November 18, 2020 was 40.93\%), the structure of this fund is focused on shares of high-tech companies. The profitability of some mutual investment funds of "Sberbank Asset Management" in 2020 is presented in table 2. 
Table 2. Open mutual investment funds of "Sberbank Asset Management" with the highest profitability in 2020

\begin{tabular}{|l|l|l|c|}
\hline \multicolumn{1}{|c|}{ Mutual Investment Fund } & Share cost, P / pyб. & $\begin{array}{l}\text { Net asset } \\
\text { Value/CYA, } \\
\text { MJH pyo. }\end{array}$ & Yield, year \% \\
\hline The Fund's «Global engineering» & 632,92 & 33,52 \\
\hline The Fund's «Consumer sector» & 1486,12 & 1848,88 & 54,89 \\
\hline The Fund's «Europe» & 3361,12 & 117,72 & 21,97 \\
\hline The Fund's «Emerging Market» & 1057,44 & 370,12 & 36,54 \\
\hline The Fund's «Global Internet» & 2019,45 & 7497,45 & 56,77 \\
\hline The Fund's «Global Stocks» & 4987,13 & 2014,51 & 43,09 \\
\hline The Stock fund «Electroenergetics» & 2653,53 & 1347,18 & 25,41 \\
\hline The Fund's «Gold» & 1389,34 & 34397,39 & 48,59 \\
\hline The Fund's «Biotechnologies» & 1641,91 & 1676,23 & 47,71 \\
\hline The Fund's «Eurobonds» & 1444,54 & 2206,37 & 23,90 \\
\hline
\end{tabular}

The data presented in the table show that regardless of the volume of the fund's net asset value, the fund's profitability can range from 20 to $57 \%$. It should be noted that there are funds with a lower profitability, which reaches less than $8 \%$. These are such funds as the Global Debt Market Fund, Natural Resources Fund, Ilya Muromets Fund, Dobrynya Nikitich Fund. This conclusion indicates that funds that are not rationally invested have a high risk of a low level of profitability or even negative profitability. Therefore, while trying to make a more rational decision on the formation of an investment portfolio, it is necessary to rely on a holistic analysis of possible financial instruments, which will make it possible to select alternative and profitable investment instruments. Within the framework of this study, such an alternative is the ETF presented by the foreign company FinEx.

FinEx Company is a growing international investment group of a high level. In Russia the company offers innovative investment tools and solutions that focus on maximizing the profits of all participants, cover the activities of 13 ETFs on the Moscow Stock Exchange .

First of all, it is necessary to consider FinEx, as one of the most promising drivers of development of the Russian stock market, which provides an opportunity to buy ETFs of various assets and from various foreign countries (for example, USA, Germany, China, Russia, Kazakhstan, ETF for gold, Eurobonds) [12].

In November 2020, the profitability leader among all ETFs traded on the Moscow Stock Exchange was the ETF for shares of US IT-sector ( FXIM ). This new fund was launched on 17 November 2020. The projected rate of return stems from in the strength of the global trend for digitization and high level of information technology development. At the same time, a high level of profitability is shown by the ETF for Chinese shares FXCN, the profitability in rubles was $59.98 \%$ per annum, a high level of profitability is also shown by the precious metal fund - ETF for gold ( FXGD ), it showed a yield of 50.25\% per annum.

A significant increase in profitability of ETFs can be attributed to the success of large, high-tech US companies such as Google, Apple, Microsoft, the shares of which provide a high level of shares profitability in the US IT - sector. The specifics of the industry determines the low debt burden, due to high inventory levels. As companies in different industries increase their spending on retooling their enterprises, the revenues of tech giants can also grow.

Except for the technology sector, the highest growth rate demonstrate the US broad market fund (FXUS) $-41.12 \%$ per annum, if paid in rubles. A significant contribution to the growth in the value of assets was made by such sectors of economy as technology, consumer and finance. Most investors are focused on the US stock market, which forms the basis of the investment portfolio, thus the behavior of investors and their influence on the markets of other countries depends on the value of their quotes. 
It should be noted that at the end of 2019 the entire pool of FinEx ETFs shows positive returns. The lowest level of ETF profitability was shown by the short-term US government bonds with ruble hedge ( FXMM ). This may be explained by the fund's structure, since half of the index are assets of energy companies. They suffer from high volatility in oil prices, slowdown in industry [12]. Table 3 shows all FinEx ETF indices and their 2020 returns.

Table 3. Profitability of FinEx ETF indices for 2020

\begin{tabular}{|c|c|}
\hline ETF & Profitability, $\%$ \\
\hline Global market stocks (FXMO) & 39,75 \\
\hline Global market stocks with a ruble hedge (FXRW) & 15,7 \\
\hline US short-term bonds (FXTB) & 19,97 \\
\hline US short-term bonds with a ruble hedge (FXMM) & 4,54 \\
\hline ETF Gold (FXGD) & 50,25 \\
\hline ETF tracing Russian stocks (FXRL) & 9,21 \\
\hline ETF tracing US IT-sector (FXIM) & 72,76 \\
\hline ETF tracing US (FXUS) & 41,12 \\
\hline $\begin{array}{l}\text { Eurobonds of Russian issuers with a ruble hedge } \\
\text { (FXRB) }\end{array}$ & 7,3 \\
\hline Eurobonds of Russian issuers (FXRU) & 24,63 \\
\hline ETF tracing German stocks (FXDE) & 24,18 \\
\hline ETF tracing Chinese stocks (FXCN) & 59,98 \\
\hline ETF tracing Kazakhstan stocks (FXKZ) & $24,84 \%$ \\
\hline
\end{tabular}

A positive trend in the functioning of exchange-traded funds in the Russian market indicates that at the end of 2019 , there were no funds with negative returns, more than $1 / 2$ of ETFs show a return of more than $20 \%$. Assessing the current profitability of instruments, the size of the commission, transparency and liquidity determines the proportion of investments in funds: $75 \%$ of assets in ETFs, $25 \%$ of assets in mutual funds. The finding of the presented research is that the investment in ETFs is less risky, with the lowest costs for commission.

The yield strength levels of analysis, the average yield on ETFs exceeds the yield on mutual funds. ETFs are less risky as the first investment instrument, so the main share of investments should be concentrated in them. Investments in the amount of $25 \%$ are focused on mutual funds and serve, first of all, to diversify risk and obtain high returns due to the possibility of investing in mutual funds with high income.

The majority of ETFs in the world are based on the six major indexes.

The investment time period is very important. Let's say you bought a fund using the S\&P 500 index. Its dynamics over short time periods is wave-like: over the year (September 2018 - September 2019) it went down by $0.95 \%$, in August 2019 it lost 5.2\%, and over three years it grew by $32.3 \%$. 


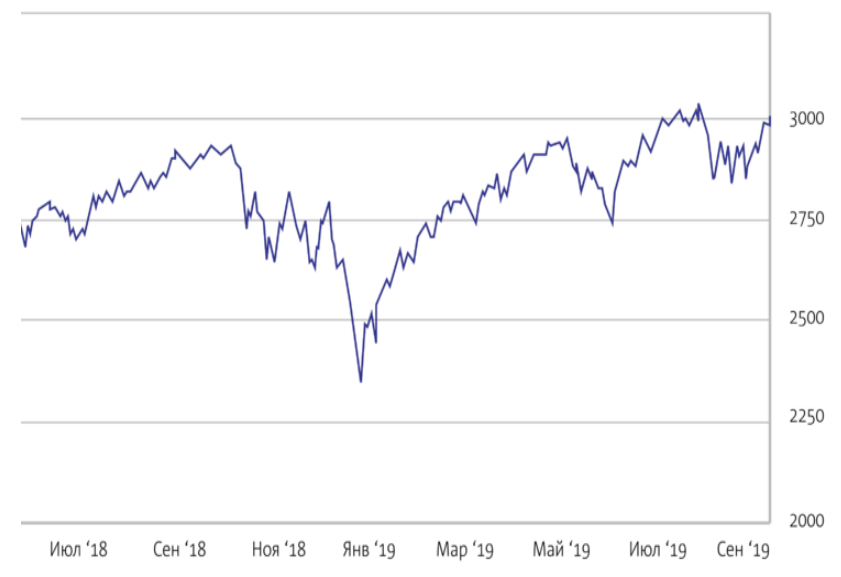

Fig. 1. Dynamics of the S\&P 500 index for three years, according to Invest Funds

ETFs give average returns. Let's say two managers or two traders chose a different pool of companies to buy their shares, the growth prospects of which they considered convincing. One bet and won more than the stock index, the other lost. The ETF will closely follow the market average return, the index. Good or bad is a matter of individual choice.

ETF FXRU (index for Russian corporate bonds) showed a yield of $20.1 \%$ in rubles for 2018, the fund units themselves are denominated in dollars.

The fund for world gold prices - FXGD - grew by $18.3 \%$ last year (again, investments are in dollars, returns are shown in rubles).

ETF is suitable for beginners only on one condition: investments are planned for a long time. It will be more expensive to speculate on exchange-traded funds. First, a broker charges a commission for each buy and sell action. Second, you need to be well-educated in global finance and economics.

The external geopolitical background is constantly putting pressure on Russian financial markets. The country's economy is showing weak dynamics. The growth rate of Russian GDP in 2020 decreased significantly due to the influence of external and non-economic factors. All international rating agencies maintain Russia's sovereign investment grade ratings. The value of net assets of open-ended funds continues to grow against the background of continuing losses of bond funds, the maximum increase since the beginning of the year was demonstrated by mixed funds and equity funds. There has been a large relative rise in index funds and money market funds.

\section{Conclusion}

The present study offers a number of important discoveries. The deviations between ETFs of foreign and Russian origin are notable. Similarly, to mutual investment fund you can buy and trade ETFs shares on the stock exchange in real time at the market price. But if the classic ETFs simply follow the index and the role of managers is reduced only to collecting a portfolio of assets similar to the index, then an exchange-traded mutual fund implies more active management.

Formally stock mutual investment funds also correlate with the index. Such funds allow to deviate from the structure and to acquire different assets or to rebalance the assets, if necessary.

Some Funds limit the deviation rate. For example, ETFs managed by Sberbank are limited to $3 \%$, others, on the contrary, do not impose strict restrictions, AKNX's 
investment policy is designed so that the fund can buy many other assets, not just those included in the designated index.

Advantages of exchange-traded mutual funds over standard mutual funds are as follows:

- unit prices fluctuate during the day, i.e. they are not fixed;

- buying / selling shares is done in real time at market price on the Moscow Stock Exchange;

- the structure of the assets of ETFs is always transparent. The structure is displayed on the official website of the Moscow Exchange, while the structure of mutual investment funds is often disclosed. It may be only shown on the website of the Management Company and is updated 1 time in every 3 months;

- shares of ETFs are purchased instantly, orders for the purchase of a unit mutual investment fund are executed within several days;

- commission of ETFs is lower than that of unit investment funds;

- the profit of ETFs is reinvested, which ensures the growth of the fund's capital and thereby ensures the growth of quotations;

- ETFs have a low entry level (in November 2020 the entry level started from 1000 rubles).

Despite the number advantages, the functioning of stock mutual funds have a number of disadvantages:

- the information is still not disclosed well enough. For ordinary ETFs you can always see what they are investing in, and the information is given on independent platforms (auditors publish the information). And for exchange-traded mutual funds you only get the information which managers wanted to show;

- commissions are still large compared to ETFs, e.g. average $0.8-1.5 \%$ vs $0.1-0.5 \%$;

- there are certain non-trading risks, since the entire infrastructure of an exchangetraded mutual fund is usually "tied" to the management company - but the control and functioning of the ETF is provided by an independent company.

Based on the nature of stock mutual funds, we can say that this category of financial instruments are presented as a hybrid between a traditional Russian mutual investment fund and foreign ETFs.

After entering the Russian stock market ETFs became available to Russian clients. At last, Russian indices of stocks and bonds are traded both in rubles and foreign currency (dollar /euro). Until 2017 on the Moscow Stock Exchange it was only possible to buy the assets of foreign ETFs, provided by management companies Finex and ITI. These ETFs followed the foreign indices and specific indices in Russian currency (namely, the Russian commodities and Raw Materials Exchange index and the Russian Eurobond indices).

All foreign securities, including ETFs, are prohibited by law for government officials and many Russian institutional investors (such as pension funds), and Russian ETFs can act as a legitimate alternative investment option.

All Russian ETFs are "Flow-through entity", this means that, according to the rules of the Russian Federal Tax Agency, "the unit mutual investment fund" (both exchange and normal) are not taxed when buying or selling Russian securities, obtaining dividends and coupons. All taxes are transferred to the final investor (there are also a number of tax incentives for investors), while foreign ETFs that specialize in Russian securities pay the tax, which may explain the low popularity of Russian ETFs among foreign investors.

Foreign ETFs traded on the Moscow Exchange use hedging options and synthetic replication in their strategies. This is necessary because there is a high level of volatility, which causes significant fluctuations in the value of shares. Synthetic replication is typically 
used by small foundations that do not have enough resources for physical replication. Both options - hedges and synthetics - are complicated by the additional costs of managing companies, higher commissions, and add additional counterparty risk. Russian ETFs do not use either hedging or synthetic replications.

A distinctive feature of Russian ETFs against foreign ETFs is the application to the Utilized Research Institute Depository which is controlled by the operating companies. They do not use the comfort of sharing the basic units between the management company and the market-maker. In addition, there are no legal requirements to maintain liquidity and the accurate tracking of the index.

Many Russian ETFs, tracking foreign indices, choose the most simple strategy, buying similar ETFs on foreign platforms, imposing a higher commission. Judging by the investment strategies, all stock exchange mutual investment funds tracking foreign indices follow this strategy, except for Sberbank stock exchange mutual investment fund, which independently replicates the S\&P 500 index through the purchase of a certain pool of shares.

All exchange-traded products on the Moscow Exchange (including Russian exchangetraded mutual investment funds) have a rather small circulation history that does not capture a single financial crisis, the Russian stock market has no practice of liquidation of ETF or stock exchange mutual investment fund liquidation in Russia. So it is worth considering the possible impact external factors.

At the same time, summarizing the study, it is worth noting that exchange-traded mutual funds in Russia are a developing, but already actively attracting investors. A promising ETF market can act as an alternative form of traditional mutual investment funds that have growth potential due to their advantages, i.e. low commission, high liquidity, transparency.

\section{References}

1. V.E. Frais, L.I. Yuzvovich, Financial Economics Journal, 7 (2020)

2. L. Deville, Exchange Traded Funds: History, Trading and Research, Handbook of Financial Engineering, 1 (2008)

3. M. Mussavian, L. Hirsch, Journal of Alternative Investments, 5 (2002)

4. PwC. 2016, ETFs: A Roadmap to Growth, https://www.pwc.com/

5. G. Rompotis, The journal of trading, 10, 56 (2015)

6. A.E. Abramov, Investment funds: return and risks, portfolio management strategies, investment objects in Russia, 416 (2005)

7. V.H. Dedegkaev, I.A. Sopoeva, D.R. Kamberdieva, Product improvement strategy in the Russian market. 21st century: fundamental science and technology, Materials of the II international scientific and practical conference, 315 (2013)

8. I.A. Sopoeva, D.R . Kamberdieva, Economics and Business Journal, 4-2, 546 (2017)

9. M.P. Loginov, V.A. Tatyannikov, Exchange-traded funds as a universal tool for digitized asset trading 1st International Scientific Conference, Modern Management Trends and the Digital Economy: from Regional Development to Global Economic Growth (2019)

10. Investment Company Institute, https://www.ici.org

11. Sberbank asset management, https://www.sberbank-am.ru/

12. International investment group of companies FinEx, https://finex-etf.ru/ 